\title{
Optimisme dan Skeptisisme Peran Hukum Dalam Pembangunan Ekonomi di Indonesia
}

\author{
Argo Trinandityo \\ Magister Ilmu Hukum, Universitas Indonesia \\ Email Korespondensi: argo.trinandityo@gmail.com
}

\begin{abstract}
Abstrak. Hukum dan Ekonomi merupakan dua disiplin ilmu yang senantiasa berinteraksi di hampir setiap aspek kehidupan manusia, bahkan terlebih lagi selalu hadir dalam setiap aktivitas yang dilakukan oleh manusia. Oleh karena itu mengingat bahwa kedudukan manusia adalah sebagai elemen terpenting dalam suatu negara, maka dalam rangka pembangunan suatu negara diperlukan pembangunan manusia yang harus ditopang oleh pembangunan ekonomi dan hukum negara tersebut, termasuk di Indonesia. Untuk dapat lebih memahami bagaimana membangun ekonomi dan hukum di Indonesia, maka terlebih dahulu diperlukan pemahaman yang lebih menyeluruh mengenai peran dan daya dari masing-masing disiplin ilmu tersebut, termasuk mempelajari cara pandang ahli hukum terhadap ekonomi dan sebaliknya juga mencoba memahami cara pandang ahli ekonomi terhadap hukum baik dalam bentuk optimis maupun skeptis.
\end{abstract}

\section{Kata kunci: Hukum dan Ekonomi, Pembangunan Negara, Peran Hukum dalam Pembangunan Ekonomi}

\begin{abstract}
Law and Economics are two disciplines that always interact in almost every aspect of human life, even moreover its always present in every natural activity carried out by humans. Therefore, given that human position as the most important element in a country, in the framework of the development of a country human development is required, that must be supported by economic development and the laws of the country, including in Indonesia. To be able to reach a better understanding about how to build the economy and law in Indonesia, a more thorough understanding of the role and power of each discipline is mandatory needed, including learning the way how legal experts view regarding the economy and on the contrary also try to understand about the way how economists view regarding the law, in both optimistic and skeptical form.
\end{abstract}

Keyword: Law and Economics, Nation Development, Legal Role in Economic Development

\section{PENDAHULUAN}

Hukum dan Ekonomi merupakan dua disiplin ilmu yang saling berkaitan satu dengan lainnya, terutama di masa modern seperti sekarang ini. Keduanya senantiasa hadir dan bahkan tidak jarang bertentangan satu dengan lainnya di setiap disiplin ilmu lainnya yang ada di muka bumi ini. Hampir dalam setiap aktivitas manusia yang rasional, yang selalu menjadi pertanyaan mendasar adalah "bagaimana hukumnya?" dan "bagaimanakah dampak ekonominya?"

Sebagai contoh misalnya dalam bidang kedokteran, ketika ditemukan adanya suatu metode pengobatan yang baru, akan muncul dua pertanyaan mendasar tersebut di atas. Demikian pula halnya dalam bidang sains dan teknologi, politik, sosial, budaya, dan lain sebagainya.

Dalam aktivitas yang paling rutin dan sederhana sekalipun, setiap hari seseorang baik secara sadar ataupun tidak, juga hampir selalu mempertimbangkan kedua aspek tersebut di atas. Sebagai contoh, dari sejak bangun di pagi hari, akan muncul pertanyaan dalam benak seseorang, "Apakah bila saya tidur lagi maka saya akan mengalami keuntungan atau kerugian?" dan Apakah dengan tidur lagi maka saya akan melanggar kewajiban saya atau tidak? (misalnya terhadap perjanjian kerja).

Hal tersebut berlanjut hingga malam hari ketika seseorang tersebut hendak tidur akan muncul pertimbangan akankah dia tidur sekarang ataukah nanti setelah selesai 
mengerjakan tugasnya? Di manakah saya akan tidur? di kantor ataukah di rumah? Dan lain sebagainya. Semua pertimbangan umumnya akan mengerucut kepada pertimbangan hukum dan ekonomi.

Hal tersebut tidaklah mengherankan karena baik hukum maupun ekonomi merupakan refleksi dari pemenuhan kebutuhan manusia. Ekonomi memberikan alat-alat untuk memenuhi kebutuhan manusia, dan hukum memberikan perlindungan atau rasa aman bagi pelaksanaan pemenuhan kebutuhan manusia itu sendiri. Oleh karena itu pembangunan negara sebagai kumpulan dari manusia pada dasarnya akan bergantung kepada pembangunan ekonomi dan hukumnya.

Erman Rajagukguk secara umum membagi dua kelompok besar yakni yang menganut pandangan optimis di satu sisi, dan yang menganut pandangan skeptis di sisi lain, yang akan saya elaborasi lebih dalam tulisan ini dengan membahas Peran Hukum Dalam Pembangunan Ekonomi di Indonesia, dan sebaliknya Peran Ekonomi Dalam Pembangunan Hukum di Indonesia.

\section{PERAN HUKUM DALAM PEMBANGUNAN EKONOMI DI INDONESIA}

Di dalam buku "Peranan Hukum dalam Pembangunan Ekonomi”, Erman Rajagukguk mengemukakan bahwa dalam kajian hubungan hukum dengan pembangunan, para ahli terbagi menjadi 2 (dua) kelompok yakni kelompok yang optimis dan yang skeptis.

Kelompok yang optimis berpandangan bahwa hukum memainkan peranan penting dalam menentukan prospek pembangunan, sehingga sistem hukum akan mampu mengubah situasi, dan oleh karenanya para ahli hukum akan memegang peranan penting untuk mengidentifikasi pembaharuan hukum yang mendorong pembangunan.

Saya melihat bahwa kelompok yang optimis tersebut dipengaruhi oleh pandangan Roscoe Pound, bahwa hukum (sebagai) bentuk perubahan sosial yang mengarahkan kepada tercapainya keharmonisan sosial (masyarakat). "law a form of social change directed toward achieving social harmony." Kelompok yang optimis tersebut memiliki keyakinan bahwa dengan dilakukannya pembangunan hukum yang baik (terlebih dahulu) maka akan mendorong tercapainya pembangunan ekonomi yang lebih baik pula.

Sebaliknya kelompok yang skeptis berpandangan bahwa pembangunan ekonomi akan terus berjalan bahkan mendahului pembangunan hukum, sehingga dengan kata lain peran hukum dalam pembangunan ekonomi hanya bersifat suplemen saja. Pandangan tersebut didasari atas perkembangan yang sangat pesat di Asia, khususnya China, yang tidak begitu populer dengan kemuktahiran pembangunan hukumnya, tetapi justru mengalami pembangunan ekonomi yang luar biasa mengalahkan banyak negara-negara yang ekonominya sudah maju terlebih dahulu.

Adapun sebagai contoh adalah dalam hal Trust Law di China, konsep "Trust Fund" yang diadopsi dari Common Law menimbulkan banyak kerancuan dan ketidakpastian hukum dalam pelaksanaannya di China yang menganut Civil Law, akan tetapi lembaga tersebut justru berkembang pesat dari tahun ke tahun (tercatat dana kelolaan Trust Fund pada tahun 2004 sebesar USD 24,51 milliar melonjak hampir 100 kali lipat menjadi USD 2,24 trilliun pada 2014, padahal dalam kondisi kesimpangsiuran hukum dan terjadi putusan pengadilan yang bertentangan satu dengan lainnya dalam perkara Trust Fund tersebut) .

Sebagai salah satu negara berkembang yang sedang gencar melakukan pembangunan ekonomi, Indonesia secara umum menempatkan hukum sebagai kerangka pembangunan ekonomi negara. Hal tersebut didasarkan pada ketentuan Pasal 1 ayat 3 konstitusi Undang-Undang Dasar Negara Republik Indonesia 1945 (UUD 45) yang menyatakan bahwa "Negara Indonesia adalah negara hukum". Sedangkan hal mengenai perekonomian dalam UUD 45 itu sendiri baru ditempatkan belakangan yakni pada Bab XIV yakni Pasal 33.

Hal tersebut menjadi indikator secara tidak langsung yang mencerminkan posisi Indonesia sebagai penganut paham optimis dalam memandang peranan hukum dalam 
pembangunan ekonomi. Demikian pula halnya dalam 5 (lima) syarat utama demokrasi yang terkonsolidasi (consolidated democracy) sesuai Visi Pembangunan Politik Negara Indonesia menempatkan Pemerintah yang Berdasarkan Hukum (Rechtsstaat) sebagai syarat pertama, sedangkan mengenai Masyarakat Ekonomi yang Otonom menempati syarat kelima.

Indikator lain dari pentingnya hukum dalam pembangunan ekonomi negara Indonesia adalah diterbitkannya UndangUndang Nomor 11 tahun 2020 tentang Cipta Kerja (Omnibus law Ciptaker) yang dipromosikan atau digadang-gadang oleh Pemerintah sebagai masterpiece yang diharapkan mampu mengundang masuknya investasi (baik asing maupun lokal) secara masif guna memacu pertumbuhan ekonomi nasional secara signifikan. Terlepas dari pendapat pribadi saya bahwa Omnibus Law Ciptaker tersebut belum menggambarkan perubahan yang radikal atau revolusioner dalam kemudahan bisnis (ease of doing business) sebagaimana dipromosikan sebelumnya, akan tetapi ditempuhnya metode Omnibus Law tersebut mencerminkan paradigma berpikir Pemerintah yang menempatkan hukum sebagai pembuka jalan pembangunan ekonomi dalam hal ini investasi yang menciptakan banyak lapangan pekerjaan baru baik sebagai pelaku usaha (enterpreneur) maupun sebagai tenaga kerja (buruh).

Selain daripada paradigma berpikir Pemerintah yang menempatkan hukum di atas ekonomi, masyarakat Indonesia pada umumnya termasuk juga para ahli hukum memiliki paradigma berpikir yang sama, seperti misalnya dalam hal Arbitrase dan dalam hal Jaminan Kebendaan. Sebagaimana kita ketahui bersama, Arbitrase adalah merupakan lembaga penyelesaian sengketa di luar pengadilan guna mendukung perkembangan dunia usaha dan perkembangan lalu lintas di bidang perdagangan, sehingga berorientasi kepada perkembangan ekonomi, akan tetapi putusannya tetap harus didaftarkan dan dieksekusi di Pengadilan Negeri, bahkan lebih jauh lagi dapat dimohonkan pembatalannya ke Pengadilan Negeri.
Serupa halnya dengan Arbitrase tersebut, dalam hal Jaminan Kebendaan juga nampak paradigma berpikir yang sama dalam hal menempatkan hukum dan ekonomi. Lembaga Parate Executie baik dalam Hak Tanggungan ataupun Jaminan Fiducia seolah ditempatkan di bawah lembaga peradilan. Padahal maksud dan tujuan dari adanya lembaga Parate Executie adalah kemudahan dalam eksekusi jaminan bagi kreditur (dengan tanpa melalui lembaga peradilan) guna mendukung pertumbuhan ekonomi dengan mengurangi risiko kredit macet, yang memang sejatinya menempatkan posisi kreditur di atas debitur.

Hal tersebut dilakukan karena dalam suatu perjanjian kredit atau pinjaman atau yang sejenisnya, posisi kreditur adalah pihak yang lemah dalam perjanjian, karena sudah terlebih dahulu melaksanakan prestasinya berdasarkan perjanjian tersebut di awal pelaksanaan perjanjian, sebaliknya posisi debitur pada awal perjanjian sama sekali belum melakukan kontraprestasinya. Bahkan yang lebih mengherankan lagi, posisi kreditur yang melakukan Parate Executie justru dianggap melakukan Perbuatan Melawan hukum (padahal sedang menjalankan haknya yang diberikan oleh Undang-Undang).

Secara kontradiktif, hakim sebagai penegak hukum diserahkan untuk mengambil keputusan menyangkut ekonomi dengan penilaian dan subyektivitas hakim sebagai ahli hukum dan bukan sebagai ahli ekonomi, sehingga tidaklah mengherankan apabila sebagai salah satu dampaknya, semakin hari pengertian Perbuatan Melawan Hukum menjadi semakin luas untuk mengakomodir hadirnya kekuasaan hukum (yang notabene adalah wilayah kekuasaan hakim) ke dalam perbuatan-perbuatan yang sesungguhnya belum dapat dirumuskan secara jelas oleh hukum sebelumnya, dan sebagai akibatnya akan semakin sulit untuk didefinisikan secara pasti.

Sebagai contoh misalnya dalam aktivitas ekonomi yang dilakukan secara daring di dunia maya, akan sulit mendefinisikan mengenai perbuatan melawan hukum akibat pelanggaran kepatutan atau kesusilaan, karena pihak yang bertransaksi secara daring sangat mungkin 
berada dalam kultur masyarakat yang berbeda atau bahkan dalam hukum negara yang berbeda, sehingga akan memiliki persepsi yang berbeda dalam memaknai dan mengukur kepatutan atau kesusilaan. Padahal perbuatan yang melanggar kepatutan atau kesusilaan adalah termasuk 2 (dua) hal yang diakui bahkan dinyatakan sebagai perbuatan melawan hukum menurut Molengraaff.

Berdasarkan hal-hal tersebut di atas, maka dapatlah dipahami bahwa sekalipun kelompok yang optimis terhadap peranan hukum dalam pembangunan ekonomi di Indonesia mendominasi secara kuantitas, akan tetapi pandangan kelompok yang skeptis terhadap peranan hukum tersebut pun memiliki landasan yang cukup kuat untuk dipertimbangkan.

Pandangan tersebut khususnya lahir dari para pelaku ekonomi (bukan hanya para ekonom) itu sendiri yang justru seringkali berpandangan bahwa hukum di Indonesia lebih banyak menghambat perkembangan ekonomi dibandingkan dengan mendukung pertumbuhan ekonomi masyarakat sebagai fondasi pertumbuhan ekonomi negara Indonesia. (contoh: pengenaan pajak terhadap e-commerce yang banyak melibatkan usaha mikro dan kecil termasuk usaha rumah tangga, Jaminan Produk Halal yang menyulitkan usaha kecil atau pedagang kaki lima untuk menjamin kehalalan produknya sesuai standar UndangUndang, dan lain sebagainya). Tidak dapat dijelaskan secara ekonomi, bagaimana keberadaan aturan-aturan hukum tersebut dapat menunjang pembangunan ekonomi dan bukannya malah menjadi hambatan terhadap ekonomi).

\section{PERAN EKONOMI DALAM PEMBANGUNAN HUKUM DI INDONESIA}

Untuk mendapatkan perspektif yang lebih lengkap mengenai hubungan hukum dan ekonomi, maka pada bagian ini saya bermaksud akan menguji dari sisi sebaliknya yaitu peranan ekonomi dalam pembangunan hukum di Indonesia. Teori yang sangat berkaitan dengan hal ini adalah teori "Economic Analysis of Law".
Teori tersebut di atas secara praktis dapat diartikan sebagai melakukan intepretasi hukum melalui kacamata teori ekonomi, oleh karena itu haruslah terlebih dahulu memahami teori tentang ekonomi. Teori tersebut dikembangkan dari ide aliran 'utilitarian' atau kemanfaatan hukum yang diilhami oleh pemikiran filsuf Jeremy Bentham (17481832). Bentham sendiri tidak secara langsung mengusung teori Economic Analysis of Law, akan tetapi buah pemikirannya mengenai hukum yang seharusnya (ought to be atau should be) bermanfaat, berkembang menjadi salah satunya dari sisi kemanfaatan ekonomi. Teori tersebut justru dikembangkan oleh filsuf John Stuart Mill (1806-1873) yang notabene adalah seorang ekonom.

Keith Hylton membagi kelompokkelompok Economic Analysis of Law menjadi 4 (empat), yaitu kelompok pertama yaitu kelompok analisa hukum positif dengan analisa ekonomi positif, kelompok kedua yaitu kelompok analisa hukum positif dengan analisa ekonomi normatif, kelompok yang ketiga yaitu kelompok analisa hukum nonpositif dengan analisa ekonomi positif, dan kelompok yang keempat adalah kelompok analisa hukum nonpositif dengan analisa ekonomi normatif. Beranjak dari pendapat Hylton tersebut di atas, maka selanjutnya saya akan mencoba menganalisanya dengan situasi hukum di Indonesia.

Pada kelompok yang pertama ini, analisa dilakuan terhadap hukum positif menggunakan analisa ekonomi yang positif, yang mencoba menjelaskan sebab musabab beserta konsekwensi dari hukum positif tersebut terhadap kesejahteraan ekonomi.

Sebagai contoh konkrit dari pandangan kelompok yang pertama ini di Indonesia adalah misalnya dalam hal penelitian mengenai apakah Undang-Undang tentang Sistem Jaminan Sosial Nasional berhasil meningkatkan kesejahteraan masyarakat? Apakah hukum tersebut meningkatkan angka harapan hidup masyarakat Indonesia? Apakah seiring dengan masyarakat yang semakin sehat maka kemudian tercipta masyarakat Indonesia yang produktif sehingga penerimaan negara dari sektor perpajakan juga meningkat? 
Apakah justru menambah beban APBN (Anggaran Pendapatan dan Belanja Negara) saja dan tidak berdampak signfikan terhadap kesehatan masyarakat?

Dari hasil penelitian tersebut maka akan dapat dikalkulasi secara ekonomi apakah hukum positif tersebut perlu dipertahankan ataukah harus diubah? Metode dari kelompok yang pertama inilah yang biasanya paling sering digunakan oleh pihak-pihak yang menjalankan fungsi eksekutif sebagai evaluasi keberhasilan atas suatu hukum positif dengan metode keekonomian, untuk dapat menyesuaikan antara pelaksanaan suatu program dengan budget yang ada.

Pada kelompok yang kedua, analisa dilakuan terhadap hukum positif menggunakan analisa ekonomi yang normatif, yang mencoba mendesain, mengoptimalkan, atau mereformasi lembaga-lembaga hukum yang ada guna mencapai efektifitas dan efisiensi yang optimal. Sebagai contoh konkritnya adalah misalnya dalam hal penelitian terhadap Undang-Undang 30 tahun 1999 tentang Arbitrase dan Alternatif Penyelesaian Sengketa (UU AAPS), apakah dapat mengurangi tunggakan perkara di lembaga peradilan (yang berarti mengurangi beban operasional lembaga peradilan)? Ataukah misalnya justru UU AAPS tersebut menambah beban biaya litigasi (cost of litigation) bagi pihak-pihak yang berperkara? Apakah UU AAPS dapat meningkatkan kepercayaan investor?

Dari hasil penelitian tersebut dapat dirancangkan atau dirumuskan suatu hukum positif yang dapat menunjang tercapainya suatu tujuan tertantu yang diharapkan. Metode dari kelompok ini biasanya digunakan oleh pihak-pihak yang menjalankan fungsi legislatif dalam hal evaluasi terhadap suatu lembaga atau sistem hukum, atau guna merumuskan sistem atau lembaga hukum yang dianggap paling tepat dan berdampak optimal, untuk dapat diundangkan dikemudian hari.

Pada kelompok ketiga, analisa dilakukan terhadap hukum nonpositif dengan menggunakan analisa ekonomi yang positif. Sebagai contoh adalah dalam hal penelitian terhadap Fatwa Majelis Ulama Indonesia
Nomor 1 tahun 2004 tentang Bunga (Interest/Fa'idah) yang menyatakan bahwa bunga (Bank, Asuransi, Pasar Modal, Pegadaian, Koperasi, dan Lembaga Keuangan lainnya maupun oleh individu) adalah haram. Apakah hukum nonpositif tersebut berdampak terhadap kesejahteraan orang Indonesia yang beragama Islam? Apakah fatwa tersebut berdampak terhadap meningkatnya pendapatan Bank atau Lembaga Keuangan yang syariah?

Hasil penelitian tersebut dapat digunakan sebagai evaluasi dari suatu pelaksanaan kegiatan keuangan baik individu ataupun lembaga yang beragama atau berasaskan Islam. Metode ini bisa digunakan misalnya oleh Komisi Pengawas Persaingan Usaha (KPPU) untuk menentukan dan memutuskan apakah fatwa ini dapat dikategorikan sebagai bentuk persaingan yang tidak sehat dari lembaga keuangan syariah ataukah memang demi kesejahteraan umat Islam di Indonesia dan tidak ada hubungannya dengan persaingan usaha?

Pada kelompok yang keempat, analisa dilakukan terhadap hukum nonpositif dengan menggunakan analisa ekonomi yang normatif. Sebagai contoh adalah dalam hal penelitian terhadap perkawinan beda agama. UndangUndang Perkawinan Indonesia tidak mengatur mengenai keabsahan perkawinan beda agama antara calon suami dan istri.

Penelitian dapat dilakukan untuk mengetahui bagaimanakah perumusan yang paling optimal dalam lembaga hukum perkawinan mengenai perkawinan yang dilakukan oleh calon pasangan yang berbeda agama? Bagaimanakah pencatatan perkawinan pasangan yang berbeda agama (misalnya antara agama Islam dan Budha) apakah akan dicatatkan oleh Kantor Urusan Agama (KUA) atau oleh Dinas Kependudukan dan Catatan Sipil (Dukcapil)?

Hasil penelitian tersebut dapat digunakan sebagai pertimbangan umumnya bagi pihak-pihak yang menjalankan fungsi legislatif untuk dapat merumuskan kaidah hukum yang dianggap paling optimal secara pertimbangan biaya beserta manfaat yang diharapkan. Pertimbangan juga dapat 
dilakukan misalnya bagi hakim yang akan memutus suatu perkara yang belum ada dasar undang-undangnya apakah akan menggunakan hukum non positif tersebut sebagai dasar pengambilan putusannya.

Berdasarkan hal-hal tersebut di atas, maka kita dapat melihat dengan lebih jelas lagi bahwa ekonomi memiliki peranan yang signifikan dalam pembangunan hukum. Hal tersebut bukan berarti bahwa segala sesuatu mengenai hukum hanya diperhitungkan manfaat ekonominya saja, akan tetapi dalam pembangunan, perumusan ataupun penegakkan hukumpun harus dipertimbangkan juga biaya dan manfaatnya secara rasional, sesuai dengan prinsip keekonomian.

Sebagai contoh misalnya hukum jelas menyatakan bahwa setiap terpidana harus menjalankan hukumannya sesuai putusan pengadilan yang berlaku, tetapi dalam hal buronan yang sudah melarikan diri belasan tahun yang lalu dan diduga hasil pidananya pun sudah hampir habis (karena sudah punya cukup waktu untuk menghabiskannya), maka apabila untuk menangkap dan memulangkan buronan tersebut membutuhkan biaya sewa pesawat ditambah biaya logistik dan akomodasi bagi rombongan pejabat beserta jajarannya akan menghabiskan dana yang jauh lebih besar daripada Stolen Asset Recovery (StAR) yang akan diperolah, maka langkahlangkah penegakkan hukumnya pun sebaiknya dapat dipertimbangkan kembali secara ekonomi. Apabila memang ternyata lebih besar manfaatnya maka berapapun biayanya tidak akan menjadi masalah.

\section{KESIMPULAN}

Hukum dan Ekonomi merupakan dua disiplin ilmu yang saling menunjang dan saling membutuhkan satu dengan yang lainnya. Kedua disiplin tersebut senantiasa beriringan dalam kehidupan masyarakat sehari-hari, karena keduanya merupakan disiplin ilmu yang mengandalkan logika atau nalar manusia, dan sebaliknya apabila ada sesuatu konsep yang salah atau bertentangan dengan logika atau nalar (baik di bidang hukum ataupun ekonomi), maka secara naluriah akan langsung dapat dirasakan kejanggalannya oleh manusia tersebut.

Oleh karena itu, baik hukum dan ekonomi, keduanya memiliki fungsi yang berbeda akan tetapi beriringan dan saling melengkapi, sehingga tidak perlu dipertentangkan siapakah yang lebih berperan, apakah hukum yang lebih berperan dalam ekonomi? Ataukah justru ekonomi yang lebih berperan dalam hukum? Maka jawabannya akan sangat beragam tergantung situasi dan kondisinya. Bagaikan kedua tangan (kanan dan kiri) di tubuh manusia, terkadang tangan kanan memiliki peran lebih besar, namun ada kalanya justru malah tangan kiri yang memiliki peran lebih besar, tergantung konteks aktivitas manusia pada waktu tertentu tersebut.

Demikian pula halnya dengan optimisme dan skeptisisme terhadap peranan hukum dalam pembangunan ekonomi di Indonesia, harus dilihat secara konteks waktu, situasi dan kondisi. Oleh karena itu, diharapkan sedapat mungkin hukum dan ekonomi dapat berkembang secara beriringan dalam suatu sinergi (AT).

\section{DAFTAR PUSTAKA}

Agustina, Rosa. (2004). Perbuatan Melawan Hukum, Cetakan kedua. Jakarta: Penerbit Program Pascasarjana Fakultas Hukum Universitas Indonesia.

Calabresi, Guido. (2019). Of Law and Economics and Economic Analysis of Law: The Role of the Lawyer. Global Jurist, vol. 19, no. 3 .

Hylton, Keith N. (2019). Law and economics versus economic analysis of law. Eur $\mathbf{J}$ Law Econ 48.

Meng, Zhen. (2016). Legal Certainty in a Contemporary Context, Legal Certainty and Trust in China. Editor Mark Fenwick and Stefan Wrbka, Singapore: Springer.

Pangaribuan, Luhut M.P. (2019). Tindak Pidana Ekonomi dan Anti Korupsi: Pengantar, Ketentuan dan Pertanyaanpertanyaan. Jakarta: Penerbit Papas Sinar Sinanti.

Rajagukguk, Erman. (2017). Peranan Hukum dalam Pembangunan Ekonomi, Cetakan pertama. Jakarta: Penerbit Universitas 
Indonesia Fakultas HukumPascasarjana.

Schofield, Philip. (2003). Jeremy Bentham's 'Nonsense upon Stilts.' Utilitas, vol. 15, no. 1.

Vago, Steven. (2009). Law and Society, 9th edition. New Jersey: Pearson Prentice Hall.

Indonesia. 1945. Undang-Undang Dasar Negara Republik Indonesia 1945.

. 1999. Undang-Undang Nomor 30 tahun 1999 tentang Arbitrase dan Alternatif Penyelesaian Sengketa, Lembaran Negara Republik Indonesia tahun 1999, Nomor 138, Tambahan Lembaran Negara Republik Indonesia Nomor 3872.

. 2020. Undang-Undang Nomor 11 tahun 2020 tentang Cipta Kerja, Lembaran Negara Republik Indonesia tahun 2020, Nomor 245, Tambahan Lembaran Negara Republik Indonesia Nomor 6573.

. Kantor Menteri Negara Perencanaan Pembangunan Nasional/Badan Perencanaan Pembangunan Nasional Indonesia, Visi dan Arah Pembangunan Jangka Panjang 2005-2025 (RPJP 20052025).

Majelis Ulama Indonesia. (2004). Fatwa Nomor 1 tahun 2004 tentang Bunga (Interest/Fa'idah).

Government of India. (2017). Ministry of Commerce and Industry, Department of Industrial Policy \& Promotion, "Consolidated FDI Policy Circular of 2017”, D/o IPP F.No.5(1)/2017-FC-1, Dated August 28, 2017. 